\title{
Reflection of actions: The Late Bronze Age hoard from Moravička Sela, north-western Croatia
}

\author{
Ohlas činů: Depot z mladší doby bronzové \\ z lokality Moraviška Sela, severozápadní Chorvatsko \\ Martina Blečić Kavur - Boris Kavur - Ranko Starac
}

\begin{abstract}
The hoard from Moravička Sela in Gorski Kotar (Croatia), discovered thirty years ago, is a medium-sized hoard with a mixed composition, containing typologically different and differently preserved objects. With its defined, most likely reduced inventory, we have acquired a smaller number of tools and weapons, half products and items of symbolic importance. Its place of discovery could be included in the distribution of the hoards of the II Late Bronze Age horizon on the broader territory of Caput Adriae and its hinterland in the $13^{\text {th }}$ and early $12^{\text {th }}$ century BC. Its composition reflects, in particular, the cultural connections ranging from the south-eastern Alpine region to the wider Pannonian and Carpathian area. Therefore, the hoard from Moravička Sela can be interpreted as a materialized act of precisely determined cultural knowledge from a broader but contemporary cultural network of meaning.
\end{abstract}

hoard - Late Bronze Age - Croatia - weapons - tools - cultural and social interactions

Depot nalezený před třiceti lety u obce Moravička Sela v Chorvatsku patř́ mezi středně velké depoty s heterogenním složením, obsahující typologicky odlišné a různě zachované predměty. Pravděpodobně neúplný soubor sestává z několika pracovních nástrojů, zbraní, polotovarů a artefaktư symbolického významu. Autoři jej v rámci chronologie oblasti Caput Adriae řadí do druhého horizontu mladší doby bronzové, tedy do 13. až počátku 12. století př. Kr. Složení depotu odráží zejména kulturní kontakty mezi jihovýchodními Alpami a pannonskou či karpatskou oblastí. Depot je proto prédstaven jako materializovaný projev dobové mentality sdílené na širokém, kulturně spř́zněném území.

depot - mladší doba bronzová - Chorvatsko - zbraně - nástroje - kulturní a sociální interakce

\section{Place and things}

The hoard of bronze items from Moravička Sela, discovered near Brod Moravice on the northern part of Gorski Kotar in north-western Croatia, was an accidental discovery (fig. 1). The biography of its assemblage is complex - 30 years after its discovery it is presented for the first time as an integral archaeological find. It was unearthed in the mid-eighties in a protected valley of Moravička Sela during ploughing on the field of Ferderber family (c.p. 5339). Its discoverers, Benjamin and Marija Ferderber, confirmed that all the items originated from a single location. It was for decades kept in private property and following the initiative of Emil Crnković and Ethno Association Turan from Brod Moravice, the items were finally again assembled and in 2017 transmitted to the Maritime and Historical Museum of the Croatian Littoral in Rijeka. The exact location of the discovery and the broader area were in detail surveyed and archaeologically documented in 2012 (fig. 2), but the intervention did not produce any additional artefacts. Despite the survey, presently, no settlements or cemeteries dating to the Late Bronze Age are known from the region and 


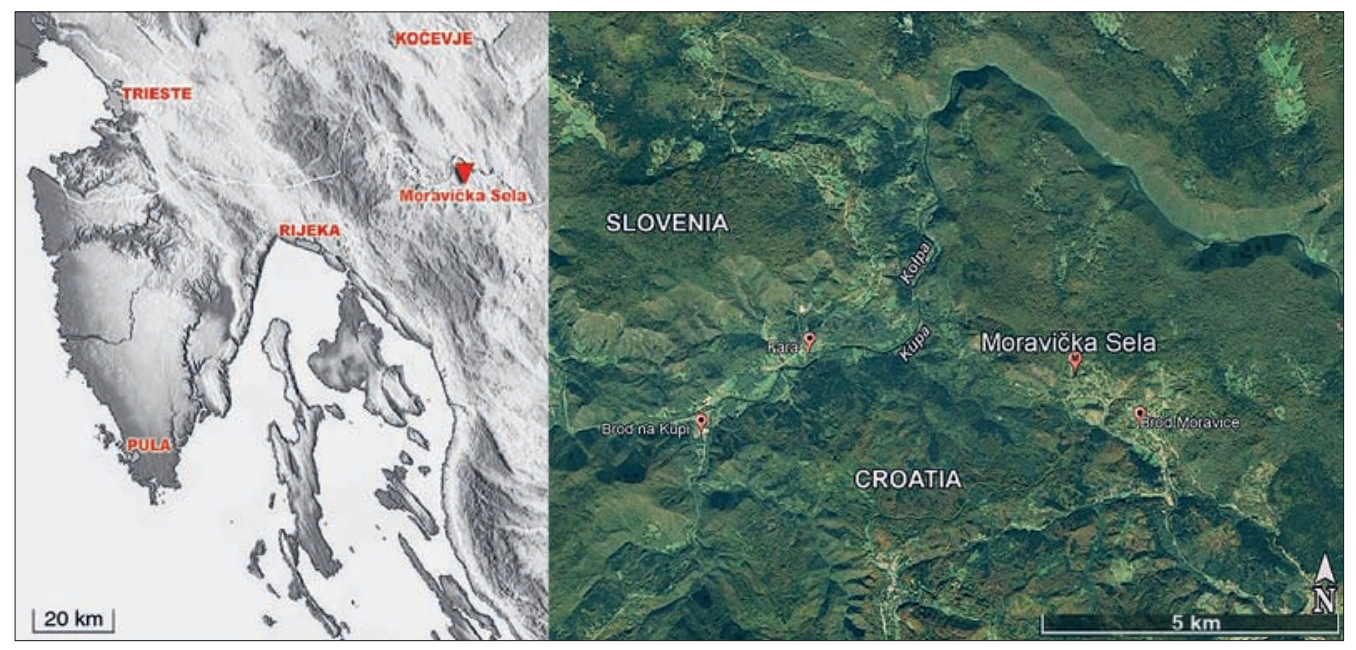

Fig. 1. Geographic position of Moravička Sela on the north protrusion of Gorski Kotar, north-western Croatia (base: Google Earth 2019). Graphics of all figs.: M. Blečić Kavur.

the hoard remains consequently further a mysterious and especially important discovery illustrating the cultural history of the region.

The preserved hoard includes a relatively small number of bronze items of different quality and meaning. It is a middle-sized hoard of mixed, i.e. of a complex composition containing 34 fragments of different but also differently preserved fragmented items weighting together 2259 grams. According to formal attributes, the content (figs. 3 and 4) could be subdivided into several categories - discovered were weapons, tools, jewellery, sheet metal and raw material (ingots):

- fragment of a flange-hilted sword with a rivet,

- fragmented miniature double pick,

- six fragments of two damaged flange-handled sickles,

- seven fragments of sickles,

- fragment of a bronze tube, most probably part of a bracelet or torques,

- fragment of a bent bronze sheet,

- two bent bracelets,

- fourteen larger and smaller fragments of ingots and pieces of amorphous bronze.

Even half of all the discovered items, forming the largest and most numerous group, were pieces of unworked metal. At least three pieces could be described as pieces if planoconvex ingots - a single larger (fig. 4: 15) and two smaller examples (fig. 4: 17-18) and smaller amorphous pieces of bronze (fig. 4: 16, 19-27) from which only a single one displays a straight surface (fig. 4: 28).

The second most numerous category of finds are fragments of flange-handled sickles made for a right-handed user. All of them were damaged - intentionally and violently fragmented. Their surfaces were badly preserved due to intensive weathering. Several of them were decorated with specific plastic reinforcement ribs on the back. A single completely preserved sickle was deliberately broken into four pieces (fig. 3: 3). It features a direct 


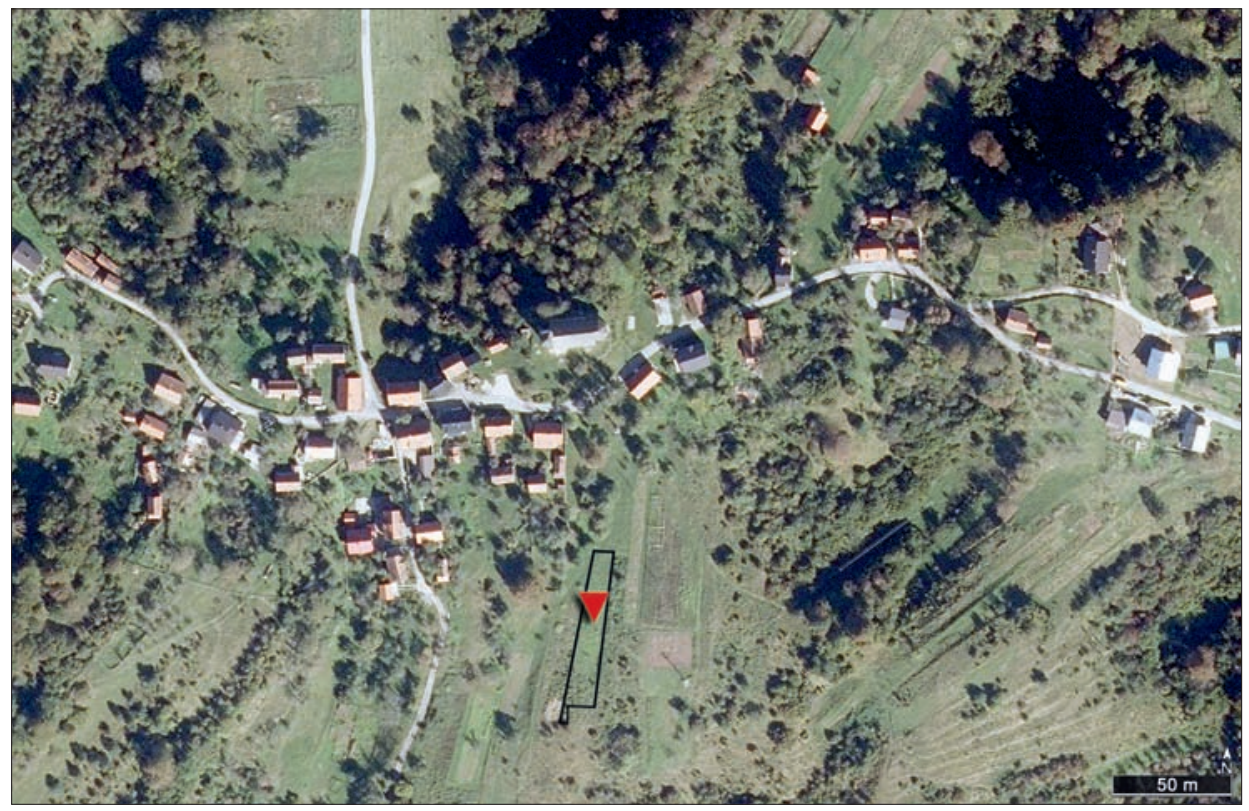

Fig. 2. Position of the hoard on the Ferderber plot (base: orthophoto Geoportal DGU/Croatian State Geodetic Administration 2019).

transition from the blade to the handle and it is decorated/reinforced with three parallel plastic ribs. It could be, according to its form, included into the group of Uioara 1 type sickles after the typology of Mircea Petrescu-Dîmboviţa and Rastko Vasić (Petrescu-Dîmboviţa 1978, 26-30, 53-57; Vasić 1994, 16-30, 40-42; Furmánek - Novotná 2006, 76-82; Jovanović 2010, 24). The second sickle, badly damaged and worn, was also broken into three pieces missing only the tip of the blade (fig. 3: 4). Characterized by a sharp transition between the handle and the blade as well as the characteristic Y shaped ornament on the handle it enables us to include it into the type Uioara 2 (Petrescu-Dîmboviţa 1978, 30-32, 53-57; Primas 1986, 91-102; Vasić 1994, 30-32, 40-42 with earlier literature; FurmánekNovotná 2006, 82-85; Jovanović 2010, 25) or the variant "a" according to Primož Pavlin $(1997,28-32 ; 2010)$. Although similar sickles are present in almost all hoards of the older phase of Urnfield culture, best comparisons could be observed in the nearby hoards of Debeli vrh nad Predgradom and Udje in Slovenia (Čerče - Šinkovec 1995, t. 64: 48; 65: 53; 137: 27-31) and Siča/Lučica in Croatia (Perkić - Ložnjak Dizdar 2005, t. 3: 46, 48, 51, 53-54). According to their distribution, they are considered being a hallmark of the southern Pannonian territory and its border region during the Ha A1 period (Hansen 1994, 205-208; cf. Sommerfeld 1994; Vasić 1994, 40-41; Blečić Kavur - Jašarević 2012, 40-41, sl. 6).

Into the category of jewellery could be included two banded bracelets with a lengthwise ridge (fig. 3: 11-12). Both have thinned and slightly bent ends that could have ended spiralled such as in the nearest examples in hoards of Debeli vrh (Čerče - Šinkovec 1995, 167, t. 66: 76) and Siča/Lučica (Perkić - Ložnjak Dizdar 2005, t. 8: 139). They could be linked to the northern-Hungarian and Slovakian territory of Carpathian Basin where such bracelets were mostly discovered in pairs (as in hoards of Moravička Sela and Debeli vrh; 

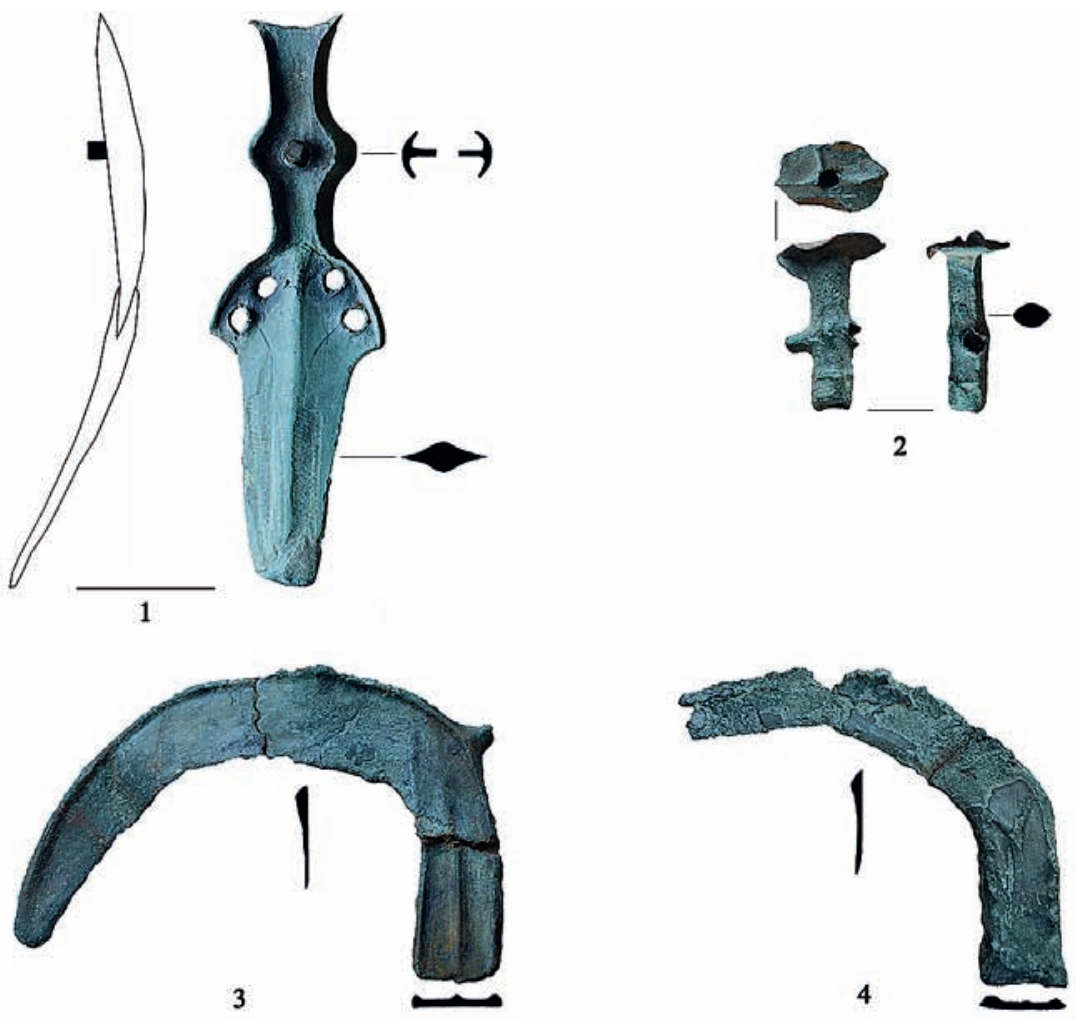

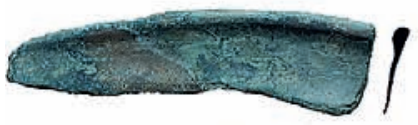

5

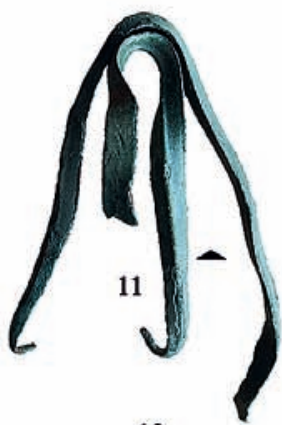

12

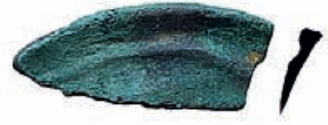

6
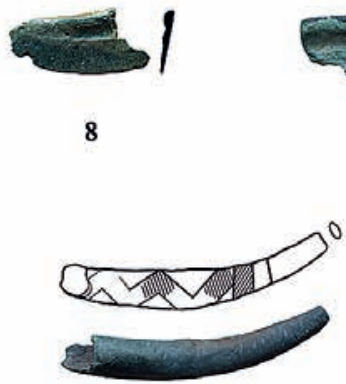

13

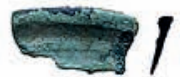

9

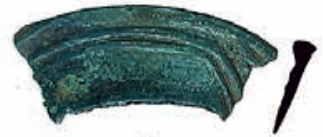

7
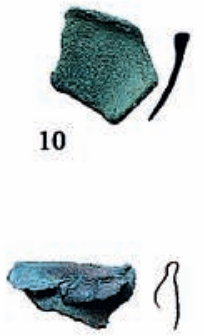

14

Fig. 3. Objects from the hoard discovered in Moraviška Sela. For the description, see the Catalogue. 

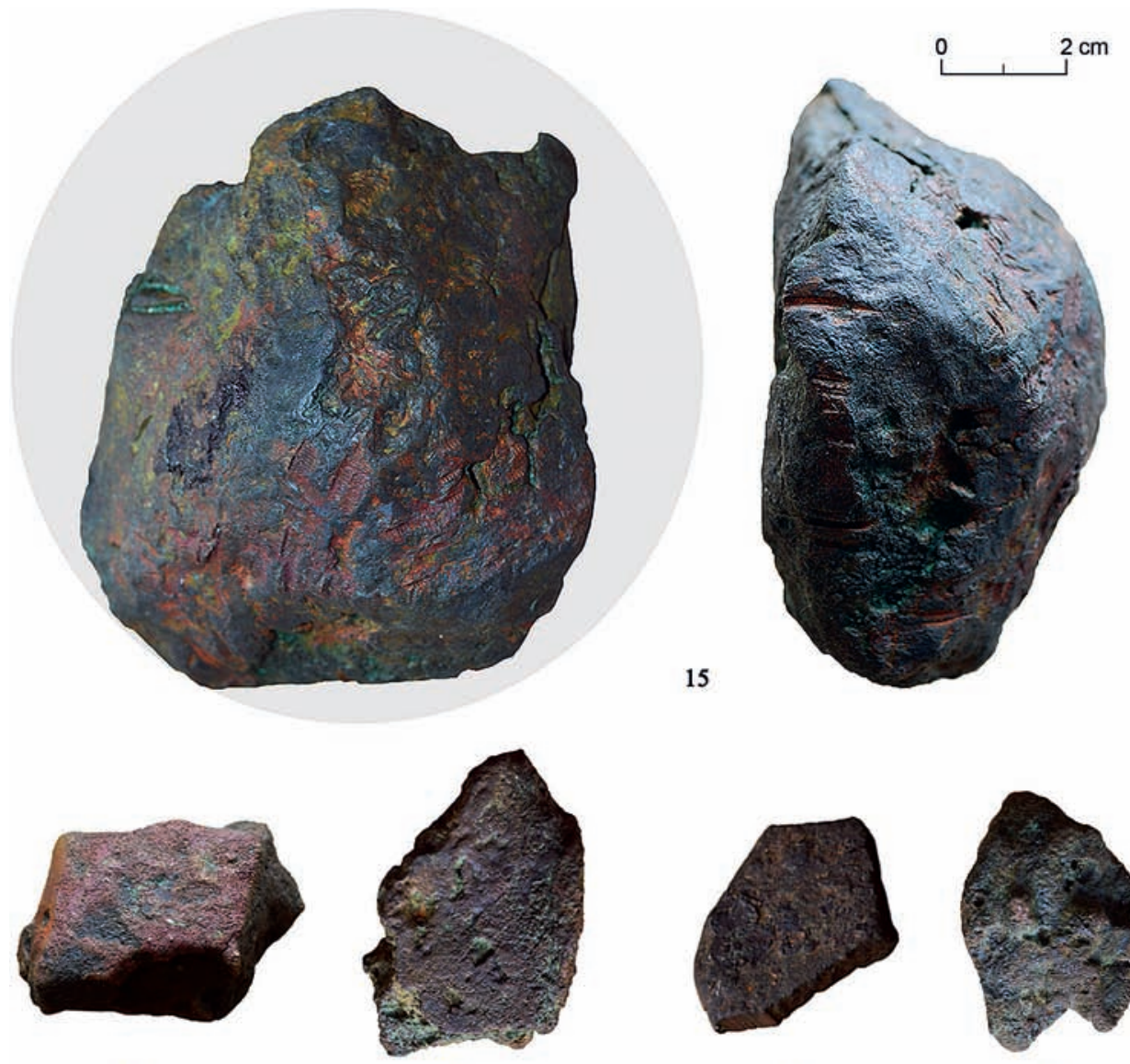

16

17

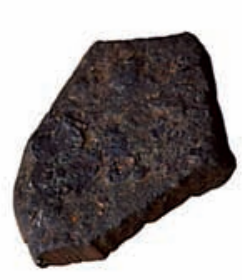

18

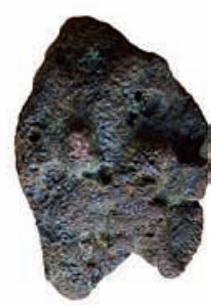

19

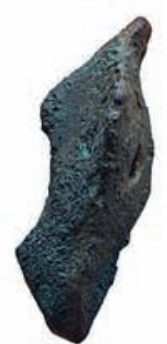

20

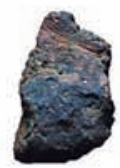

25

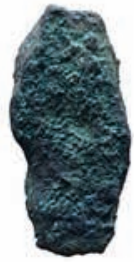

21

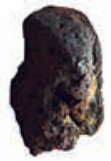

26

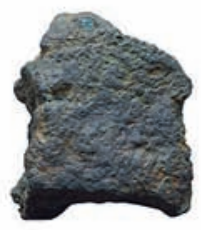

22

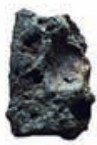

27

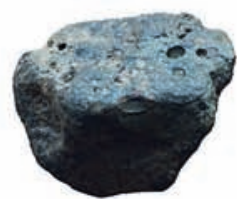

23

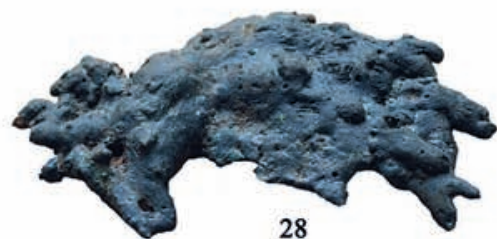

Fig. 4. Objects from the hoard discovered in Moraviška Sela. For the description, see the Catalogue. 


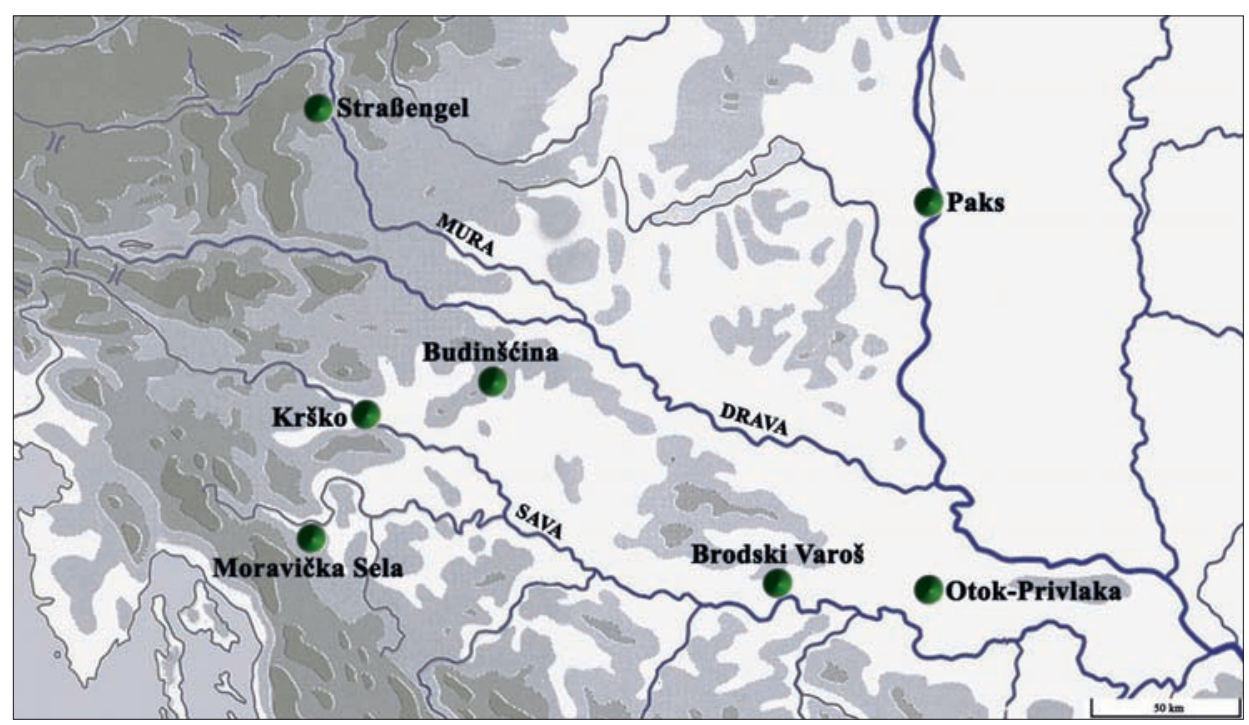

Fig. 5. Distribution of the Budinšćina/Krško type swords (supplemented after Hansen 1994; Harding 1995).

Patay 1969, 196-198, 205-207; Mozsolics 2000, 68, T. 79: 1-2; Salaš 2005, 98; cf. PerkićLožnjak Dizdar 2005, 77).

We can find in large hoards of mixed composition numerous fragments of bronze sheets, tubes and similar, mostly unidentified objects. In the present hoard was preserved a single smaller fragment of the thin bent metal sheet (fig. 3: 14). Interesting is another find - a bronze tube (fig. 3: 13), broader at the central part. It is decorated with an incised zig-zag motive within which are partly visible hatched surfaces. Smaller bronze tubes are characteristic for the Ha A1 period of the broader Carpathian and especially Pannonian territory (Tarbay 2014, 208-210, fig. 30; 42) and if they are decorated then the ornament is composed of strictly parallel incised lines as known from the nearest hoards in Siča/Lučica and Peggau (Perkić-Ložnjak Dizdar 2005, t. 11: 212-216; Weihs 2004, T. 1: 5; 3: 40). Most of these tubes, contrary to our example, do not have a broader central and narrower terminal part. Consequently, we tend to interpret it as a part of the attire, this is of jewellery. Due to its preserved length and curvature, we can assume that it could be a fragment of a larger bracelet or even more plausible a part of a larger ring used as a necklace/torques.

Weapons are represented with a fragmented flange-hilted sword (fig. 3: 1). It was intentionally bent and two thirds of the blade are missing. The tang has a perforated emphasized circular stretching in the centre and a single rivet still preserved. The interface of the hilt plate with the blade is strongly concave while the hilt plate has convex shoulders and four rivet holes. The blade has a central slightly rounded rib and is decorated with two incised lines on each side. Typologically it could be ascribed to the group A4 of flange-hilted swords as generally determined by Tibor Kemenczei (1988, t. 23: 227). These are swords of Budišćina type according to Svend Hansen (1994, 34, Abb. 14) or type Krško according to the typology of Anthony Harding (1995, 53, t. 22: 183-186). Although a regional production was assumed, their spatial distribution indicates most numerous presence on the broader territory of southern Pannonia - from Slavonia to Zagorje in Croatia and 

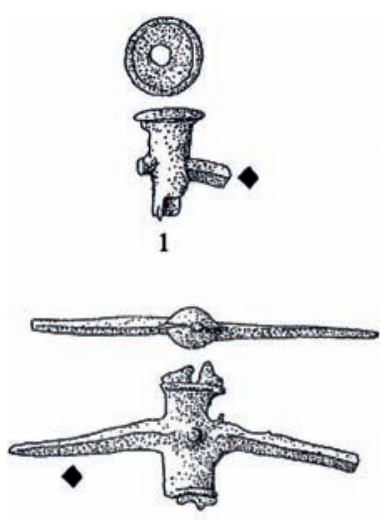

5
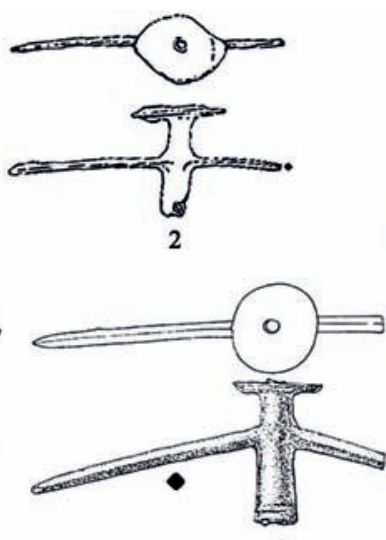

6
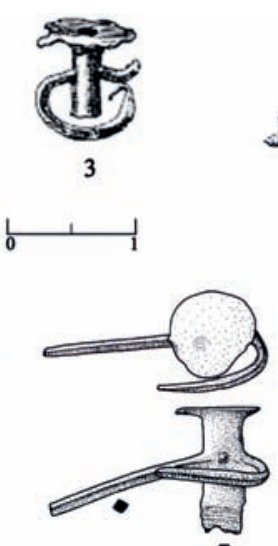

7
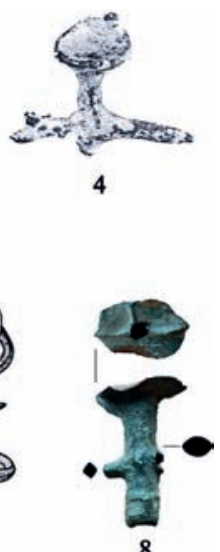

8

Fig. 6. Miniature double picks: 1 Vršatské Podhradie (after Novotná 2002); 2 Žitný ostrov (after Novotná 1980); 3 Bodrogkeresztúr (after Hampel 1886); 4 Trenčianske Bohuslavice (after Novotná 1970a); 5 Vršatské Podhradie (after Novotná 2002); 6 Dobrochov (after Salaš 2005); 7 Peggau (after Weihs 2004); 8 Moravička Sela.

Dolenjska region in Slovenia with individual finds in river valleys of Mura and Danube. With the here presented sword their distribution stretches also south from the Sava corridor into the region Kupa Basin (fig. 5).

In sharp contrast to the regional distribution of flange-hilted swords of Budinšcina/ Krško type is the wide distribution of double picks. An interesting example of the later is the special find from Moravička Sela (fig. 3: 2). Miniature in size it features a small central knob on the shaft where both "arms" are attached and a single horizontal rib is preserved on the lover part of the shaft. The oval disc-shaped terminal is of irregular form with preserved casting seams on the top and below indicating that the item was cast in a double mould. Casting seams on top of the disc form a cross around the central hole. Preserved short and thin broken "arms" indicate that the item was not produced with great care - an observation confirmed by the fact that casting seams were never removed.

Double picks are a specific form of tools, which are characteristic for the Carpathian Basin - northern part of Hungary and especially Slovakia, but they are also well represented in Bohemia and Moravia (Novotná 1980, fig. 5; Hansen 1994, 204, Abb. 124; Teržan 1996, sl. 1; Salaš 1997, 35; 2005, 72-73; 2018, 58-59; Vachta 2008, 31, Abb. 17: 18; Novotná - Furman 2018, 84-91, fig. 9). Miniature examples, however, do not belong to the usual forms (fig. 6). Due to basic morphological characteristics of discovered example, we could ascribe it to the E type according to the elaborated typology of Stanislav Stuchlík (1988, 306-317, fig. 19; cf. Novotná 1970b, 64-65; 1980, 141-144; NovotnáFurman 2018, 84-85). It is a smaller typological group with only 13 examples on 11 sites (Novotná - Furman 2018, 91-93 and here listed new sites), dated generally to the Ha A horizon according to the central European periodization (Novotná 1970b, 64-66; 2002, Abb. 3-4; Novotná - Furman 2018, 90). Until recently, these finds were characteristic exclusively for the Carpathian territory of Slovakia with individual finds in Moravia and Hungary (fig. 7). Similar examples are known from the hoards of Žitný ostrov, Vršatské Podhradie and Košické Olšany in Slovakia (Novotná 1980, t. 2: 1-2; 2002, Abb. 3; Miroššayová 1998/1999, 127-128, fig. 11), Dobrochov in Moravia (Stuchlík 1988, 316, fig. 22; 


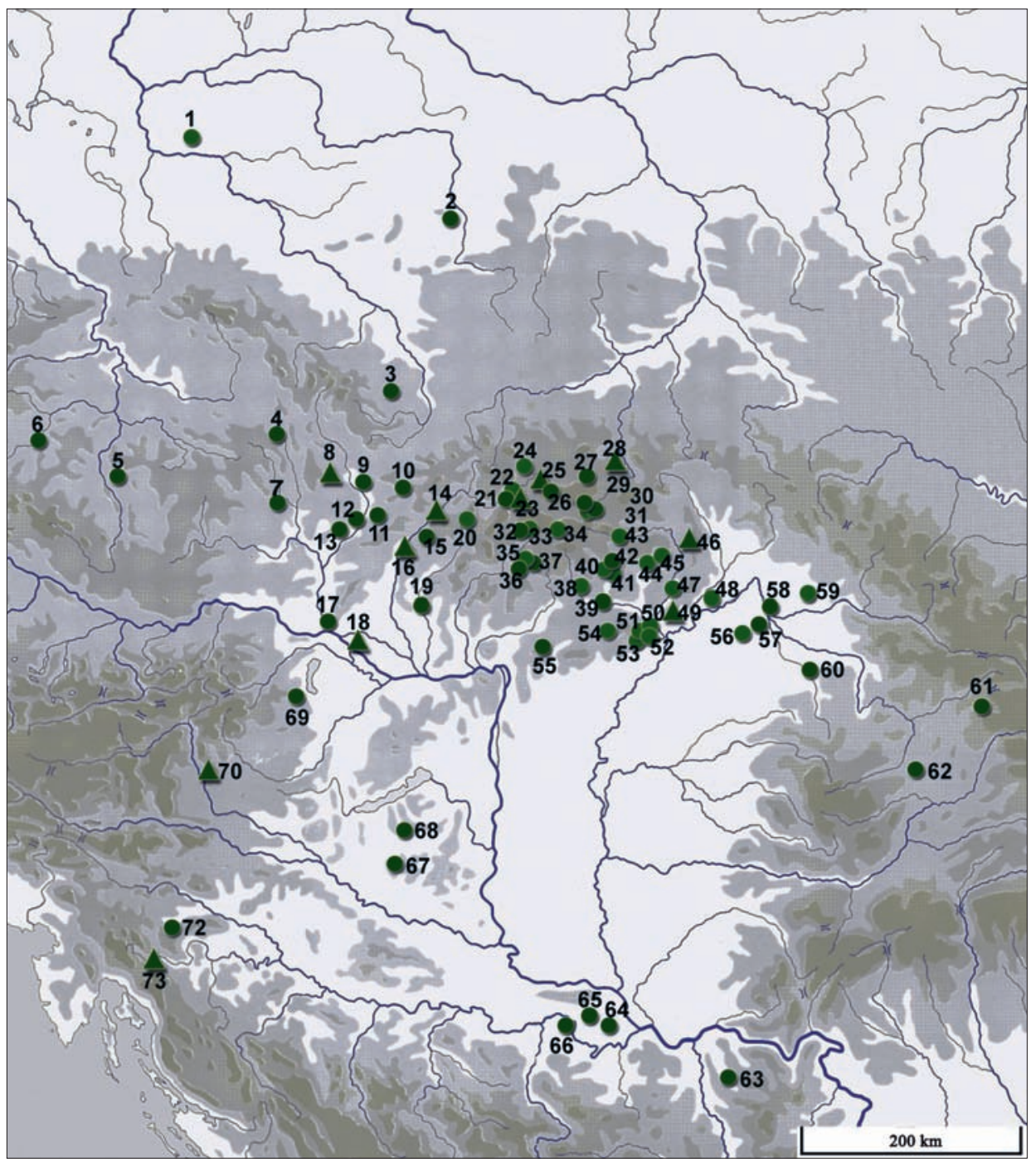

Fig. 7. Spatial distribution of double picks of Carpathian types ( $\bullet$ ) and miniature double picks ( $\boldsymbol{\Delta}$ ). Supplemented and corrected after Novotná - Furman 2018. Below, the sites of miniature double picks are marked in bold.

1 Sulechów; 2 Niechmirów; 3 Třemešná (Bříza -Stuchlík 2019); 4 Kunětice; 5 Řepeč; 6 Libákovice; 7 Ivančice 6 (Salaš 2018); 8 Dobrochov; 9 Hradisko 2; 10 Provodov (Bříza-Stuchlík 2019); 11 Drslavice 2; 12 Uherské Hradiště; 13 Polešovice; 14 Vršatské Podhradie; 15 Ĺuborča; 16 Trenčianske Bohuslavice; 17 Bratislava; 18 Žitný ostrov; 19 Nitra; 20 Lazany; 21 Blatnica; 22 Belá - Dulice; 23 Folkušová; 24 Černová; 25 Bešeňová; 26 Partizánska Ĺupča; 27 Liptovská Anna; 28 Nižná na Orave; 29 Liptovský Ján; 30 Liptovská Ondrašová; 31 Liptov?; 32 Badin; 33 Riečka; 34 Ĺubiteová; 35 Budča; 36 Ostrá Lúka, okr. Zvolen; 37 Zvolen; 38 Holiša; 39 Hostice; 40 Ožd’any; 41 Rimavská Sobota; 42 Vel'ký Blh; 43 Dobšiná; 44 Gemer; 45 Zádielské Dvorníky; 46 Košické Olšany (Miroššayová 1999); 47 Felsödobsza; 48 Viss; 49 Bodrogkeresztúr; 50 Harsány; 51 Bükkaranyos - Földvár; 52 Sajóvámos; 53 Muhi; 54 Pétervására; 55 Csitár; 56 Baktalórantháza; 57 Ópályi; 58 Krazsna; 59 Zatišnoe; 60 Domăneşti; 61 Dipşa; 62 Uioara de Sus; 63 Šetonje (Jacanović - Radojčić 2005); 64 Šimanovci; 65 Pećinci; 66 Drenovac - Šid (Церовић 2003); 67 Felsöszentlászló; 68 Szentgáloskér; 69 Oberloisdorf; 70 Peggau (Weihs 2004); 71 Austria?; 72 Jurka vas; 73 Moravička Sela. 
cf. Salaš 2005, 314, t. 102: 24; Bř́za - Stuchlík 2019, 86) and Peggau in Austrian Styria (Weihs 2004, 45-46, Abb. 41, t. 20: 147). Thus, discoveries from hoards in Peggau and Moravička Sela profoundly changed their distribution and moved the borders of their understanding within the broader cultural territory towards the south.

According to their form and decoration look most of miniature double picks similar especially due to the oval disc on top of the body, which generally has a central oval profile, lowered "arms" of square cross-section and oval, an irregular perforated body of the pick. The only decoration, present on these miniatures, was a smaller knob on the central part of the body positioned between "arms" or one, sometimes, two ribs near the upper or/and the lower part of the body. Such is the decoration of the pick from Moravička Sela - most comparable are examples from hoards Nižná na Orave (Čaplovič 1957, 775-776, fig. 313; Novotná 1970a, 108-109, T. XVII), Vršatské Podhradie, Dobrochov and Peggau (fig. 6: 5-7). Taking into consideration their decoration, they could be divided into two groups - undecorated (variant Ea) and decorated (variant Eb) as proposed by Stuchlik (1988, 308-310, fig. 19). In this second, Eb variant, the pick from Moravička Sela is the only one decorated with a cross on top of the oval disc. However, since they are poorly cast and not quite well decorated, they give us the impression that they were unfinished. It is also interesting that all the examples are marked by substantial damages - from breaking and bending of "arms" to bending of the disc and body of the pick. We could consider this observation as just another confirmation of the ritual manipulation and intentional destruction of items before their deposition. This could only reconfirm their most probably votive, but also a ritual role in the precisely defined context of the hoard.

Although the nearest known context is the one from Jurka vas hoard in Dolenjska region of Slovenia (Čerče - Šinkovec 1995, 199, t. 89: 13; 161: 9; fig. 7: 72), we have to focus of the contexts of discovery and the inventories of other hoards with miniature picks. The Peggau hoard (Weihs 2004; fig. 7: 70) is a large hoard of mixed composition and exhibits a long duration of the gathering, which contradicts the principle and deposition of Moravička Sela. Hoards from the territory of Slovakia, Moravia and Hungary are also bigger and of a complex composition although different elements of jewellery and attire as well as tools are predominant. Weapons are rare and only in hoards from Bodrogkeresztúr, Trenčianske Bohuslavice and Peggau are present flange-hilted swords (Hampel 1886, t. XCV: 21; Novotná 1970a, 121, T. XII; Weihs 2004, T. 11: 115-116). Currently, two medium-sized hoards of mixed composition are known, Moravička Sela and Dobrochovo, in which sickles are the dominant element. However, both also have a sword, which makes them comparable to the hoards mentioned above. At present, we are not able to determine a rule or pattern of weapon depositions in hoards of the core and periphery of the cultural area under discussion.

\section{Catalogue}

Catalogue number of artefacts correspond to numbers on the figs. 3 and 4:

1. Fragment of a flange-hilted sword of Budinšćina/Krško type. It was intentionally bend and broken it is missing $2 / 3$ of the blade. The handle is completely preserved. The straight tang is finishing in the form of a fishtail. The handle has emphasized flanges and is stretched in the central part with a rivet hole running through the central part of the handle. Shoulders are convex with 4 rivet holes. The blade 
is of a lenticular cross-section with a broad central rib and two parallel-incised lines. The only preserved rivet is small and has a circular cross-section

Size: length $16.5 \mathrm{~cm}$; length of the handle $6 \mathrm{~cm}$; width of the handle $2.8 \mathrm{~cm}$; width of the hilt plate $5.3 \mathrm{~cm}$; width of the blade $2.6 \mathrm{~cm}$; length of the rivet $1.7 \mathrm{~cm}$, thickness of the rivet $0.3 \mathrm{~cm}$; weight $134.52 \mathrm{~g}$.

2. Fragmented double pick, unfinished and damaged. The cylindrical tube has a small knob on the central part and a horizontal decorative rib at the bottom. Partly is preserved single arm with a rhomboid cross-section. Oval and asymmetrical plate at the top of the tube has thinner ribs forming cross-shaped enforcement. Traces of casting in a double-sided mould are visible below the disc along the edge of the tube.

Size: length $4.6 \mathrm{~cm}$; radius of the socket $1.1 \mathrm{~cm}$; length of the termination plate $3 \mathrm{~cm}$; width of the termination plate $1.8 \mathrm{~cm}$; weight $24.37 \mathrm{~g}$.

3. Flange-handled sickle of Uioara 1 type. It is preserved complete - intentionally fragmented into 4 pieces. The transition from the handle into the blade is sharp. The straight handle with a flat base is decorated with three straight ribs running to the blade. On the transition from the handle into the blade is preserved a casting plug.

Size: width $13.9 \mathrm{~cm}$; height $9 \mathrm{~cm}$; width of the blade $2.8 \mathrm{~cm}$; width of the handle $2.2 \mathrm{~cm}$; weight $51.24 \mathrm{~g}$.

4. Flange-handled sickle of Uioara 2 type. Quite damaged and used. It was intentionally damaged - preserved were $2 / 3$ of the item consisting of 2 fragments. The terminal part of the back with the blade is missing. The transition from the handle into the blade is sharp. The straight handle with a flat base is decorated with a "Y"-shaped rib.

Size: width $11.1 \mathrm{~cm}$; height $10.5 \mathrm{~cm}$; width of the blade $2.8 \mathrm{~cm}$; width of the handle $2.2 \mathrm{~cm}$; weight $47.03 \mathrm{~g}$.

5. Larger fragment of a sickle-blade with a single rib. Blade with the tip is damaged.

Size: length $10.8 \mathrm{~cm}$; width $2.8 \mathrm{~cm}$; weight $46.46 \mathrm{~g}$.

6. Fragment of a sickle-blade with the rounded tip and two ribs.

Size: length $4 \mathrm{~cm}$; width $1.7 \mathrm{~cm}$; weight $6.31 \mathrm{~g}$.

7. Fragment of a smaller sickle-blade with a single rib.

Size: length $3.6 \mathrm{~cm}$; width $1.9 \mathrm{~cm}$; weight $12.55 \mathrm{~g}$.

8. Fragment of a sickle-blade with three ribs.

Size: length $7.9 \mathrm{~cm}$; width $3.8 \mathrm{~cm}$; weight $45.07 \mathrm{~g}$.

9. Fragment of a sickle-blade with three ribs.

Size: length $8 \mathrm{~cm}$; width $4.1 \mathrm{~cm}$; weight not accessible.

10. Fragment of a sickle-blade with a thickened edge. Size: length $3.1 \mathrm{~cm}$; width $2.7 \mathrm{~cm}$; weight $10.85 \mathrm{~g}$.

11. Bent and deformed bracelet with a $D$ shaped cross-section and pointed ends.

Size: length $19.3 \mathrm{~cm}$; width $0.5-0.7 \mathrm{~cm}$; weight $18.69 \mathrm{~g}$.

12. Fragmented bent and deformed bracelet with a $D$ shaped cross-section and pointed ends.

Size: length $12.3 \mathrm{~cm}$; width $0.5-0.7 \mathrm{~cm}$; weight $13.6 \mathrm{~g}$.

13. Fragment of a bronze tube of oval cross-section. It is widening towards one end and is on both sides is decorated with an incised zigzag motive.

Size: length $7.7 \mathrm{~cm}$; width $0.5-1 \mathrm{~cm}$; weight $12.74 \mathrm{~g}$.

14. Small fragment of a bent metal sheet.

Size: length $3.8 \mathrm{~cm}$; width $2.7 \mathrm{~cm}$; weight $6.46 \mathrm{~g}$.

15. Fragment of a larger cake-shaped (convex) ingot. Polished on the lower side and on several spots incised and broken. On the surface are visible cuts and imprints of a torded object (torques).

Size: length $9.7 \mathrm{~cm}$; width $8.1 \mathrm{~cm}$; weight $1286 \mathrm{~g}$.

16. Fragment of a smaller (convex?) ingot.

Size: length $4.5 \mathrm{~cm}$; width $3.2 \mathrm{~cm}$; weight $178.04 \mathrm{~g}$.

17. Fragment of a flattened ingot with sharply cut-off sides and incisions on lateral sides.

Size: length $3.7 \mathrm{~cm}$; width $2.8 \mathrm{~cm}$; weight $45.69 \mathrm{~g}$.

18. Fragment of a flattened ingot rounded on the outer side.

Size: length $5 \mathrm{~cm}$; width $3.2 \mathrm{~cm}$; weight $74.46 \mathrm{~g}$. 
19. Fragment of an ingot.

Size: length $3.2 \mathrm{~cm}$; width $2.7 \mathrm{~cm}$; weight $65.89 \mathrm{~g}$.

20. Fragment of an ingot.

Size: length $3.2 \mathrm{~cm}$; width $2.2 \mathrm{~cm}$; weight $41.23 \mathrm{~g}$

21. Small fragment of an ingot, flat on the lower side. Size: length $4.1 \mathrm{~cm}$; width $2.8 \mathrm{~cm}$; weight $41.26 \mathrm{~g}$.

22. Fragment of an ingot with rounded cross-section. Size: length $3.8 \mathrm{~cm}$; width $1.7 \mathrm{~cm}$; weight $37.55 \mathrm{~g}$.

23. Fragment of a smaller ingot with a triangular cross-section. Size: length $2.5 \mathrm{~cm}$; width $1.8 \mathrm{~cm}$; weight $13.79 \mathrm{~g}$.

24. Small fragment of bronze. Size: length $2.3 \mathrm{~cm}$; width $1.4 \mathrm{~cm}$; weight $6.7 \mathrm{~g}$.

25. Small fragment of bronze cut on the side. Size: length $2.2 \mathrm{~cm}$; width $1.2 \mathrm{~cm}$; weight $11.24 \mathrm{~g}$.

26. Small fragment of bronze.

Size: length $1.9 \mathrm{~cm}$; width $1.3 \mathrm{~cm}$; weight $7.67 \mathrm{~g}$.

27. Fragment of bronze, most probably remains of casting in a mould. Size: length $5 \mathrm{~cm}$; width $1.8 \mathrm{~cm}$; weight $23.89 \mathrm{~g}$.

28. Fragment of molten bronze.

Size: length $9.7 \mathrm{~cm}$; width $8.1 \mathrm{~cm}$; weight $37.02 \mathrm{~g}$.

\section{The formula of time}

For a closer chronological determination of the hoard from Moravička Sela, we can use the chronologically precisely dated sword, double pick and the sickles. Swords of Budišćina/ Krško type are mostly known from hoards (Hansen 1994, Abb. 14), only the finds from Paks near Tolna (Kemenczei 1988, 49, T. 23: 227), and the eponymous sword from Krško were individual finds discovered in rivers Danube and Sava (Dular 1974, 19, t. 3: 19; Harding 1995, 53, T. 22: 185; Šinkovec 1995, 144). Taking into consideration the composition of hoards from Otok - Privlaka, Brodski varoš and Budinšćina in Croatia (Vinski-Gasparini 1973, t. 27: 10; 55: 2; 77: 5) and Straßengle in Austria (Müller-Karpe 1959, T. 126A: 23; Schauer 1971, 191-192, T. 91: 598), which are all dated to the II horizon of hoards in the broader region, their deposition could be synchronized with the Ha A1 phase of the central European periodization.

Further, such dating is supported by the chronological position of double picks - in the region on borders of the Pannonian plain in hoards from Styria such as Peggau (Weihs 2004, 45-46,) or the nearby Jurka vas ( ̌̌erče - Šinkovec 1995, 199). It is a chronological place well known for the miniature picks from hoards on the territory of Slovakia, Moravia and Hungary belonging to the Piliny and Lužice cultures at the end of $\mathrm{Br} \mathrm{D}$ and during the Ha A horizon (Novotná 1980, Abb. 3, 4; Salaš 1997; cf. Vachta 2008, 31; Novotná - Furman 2018, 88-90; Salaš 2018, 58-59).

It is also important to stress the eastern situation of their southern Pannonian distribution on the territory of Serbia. Although there are present only larger picks of Carpathian type, mostly type B, it is worth mentioning recent discoveries of hoards from Drenovac from Mačva (fig. 7: 66) and Šetonje from the territory of Mlava in southern Danube area (fig. 7: 63; see Церовић 2003; Jacanović - Radojčić 2005; cf. Blečić Kavur 2018). It is significant since their number rise to 5 examples addressing new possibilities of understanding their broader cultural and spatial interpretation. These hoards could be, according to 
their typological and stylistic analysis, dated to Ha A horizon, this is into the period of the general trend of their appearance and, obviously, their vast cultural circulation. In these circumstances, that is in cultural interactions with the Pannonian and Carpathian Basin, should be reconsidered also the banded bracelets with a lengthwise ridge which could have been parts of a larger bracelet of a spiral form, so typical for the Carpathian hoards.

Sickles on other hand correspond, with their basic form, to the widely spread phenomenon of the older Urnfield culture designating the II horizon of hoards on a vast territory ranging from Eastern Alps to central Balkans. Their largest concentration is recognized from the territory of Slavonia and Srem, especially from the so-called Sava river corridor where we could assume that they were perhaps even produced (Vasić 1994, 41; Pavlin 1997, 32, sl. 4; Jovanović 2010, 24-25; cf. Vinski-Gasparini 1983, 656; Perkić-Ložnjak Dizdar 2005, 51).

The hoard from Moravička Sela should be, according to the original context of discovery, stylistic analysis and typological classification of discovered artefacts as well as their spatial distribution, related to the II horizon of hoards on the broader territory of Caput Adriae and its hinterland (Turk 1996, 108-112, sl. 5). The latter is directly linked to the II horizon of hoards i.e. Veliko Nabrđe type in northern Croatia (Vinski-Gasparini 1973; 1983; Ložnjak Dizdar 2011) and chronologically well synchronized with Ha A1 phase of the central European periodization.

\section{Praxis and gnosis}

In its form, context and concept the hoard represent the classical deposition pattern of mostly tools and raw materials following the principles of hoards of mixed, i.e. complex composition in broader Pannonian, Carpathian and eastern Alpine regions (Hansen 1994, 326; Turk 1996, 108-112; 2012; cf. Dietrich 2014). The composition of items was not random, but deliberately collected, thoughtfully selected and systematically deposited - different levels of preservation and modes of fragmentation determine it as a hoard of especially valuable items. In ritual manipulation with deposited things, we can observe at least two different patterns - from deliberate and violent breaking to mutilation and damaging. The fragmentation of items played, in this case, a specific role of an indicator of social activities (cf. Hansen 2005; 2016; Rezi 2011; Brück 2006; 2013; Bradley 2013; Dietrich 2014). Practices, which did not modify the materiality of artefacts but transformed their status from simple bronze items into consecrated objects. All these processes, recognized in observation of material culture discovered, demonstrate social conditions, norms and practices within the Late Bronze Age societies. Reflecting generally accepted trends of thoughtful and structured destruction of items, which were in most probably decisive liminal circumstances, in a ceremonial matter and for numerous reasons excluded from the circulation of metals and raw materials (Bradley 1998; Nebelsick 2000; Hansen 2005; cf. Bradley 2013; Brück 2016; Radivojević et al. 2018).

Nevertheless, observing the biographic reflection of individual items, we can recognize, that majority of them were, in their real contexts, determined for future elaboration or transformation - such function was the main characteristic of fragments of ingots and lumps of metals. Their value was not only a consequence of their weight in bronze but also their versatility, their potential for transformation - in arms of a skilful artisan they 
could have been transformed, through the processes of knowledge and innovation, into any desired object. Due to their large numbers in hoards, numerous authors in traditional observation ascribed to fragmented sickles and their fragments a specific (pre)monetary value (Sommerfeld 1994; Pare 2013). However, it should be noted, that this is one of the rare hoards where two sickles were fragmented, but afterwards almost all the fragments were deposited together and preserved (cf. Hansen 1994, 208-209, 360). Such a practice is also known from the example of a sickle from the Dobrochov hoard (Stuchlik 1988, fig. 22: 26). A condition that could easily indicate that it was the act of violence, of fragmentation and mutilation that was the main objective of the action and not the preserved materiality of bronze. Resulting the hoard was not only the deposition of valuable items; it was a material reflection of numerous actions creating a codified specific set of information - a knowledge.

Other items, especially the sword and the miniature double pick had a completely different meaning during their "life" and during their dedication in the concept of selective deposition (Chapman 2000; Târlea 2008; Dietrich 2014). The miniature double picks must have functioned as artefacts with reinforced connotative meaning, chosen because of their association with specific spheres of action. Their presence indicates a hierarchical dimension - they were reflections of social status, real or ascribed. The symbolic meaning embedded in the deposited items were open to appropriation by all members of the burying group, which undoubtedly extended beyond the social elite using the picks.

There were numerous discussions about their use or symbolic functions, but all the authors agreed that miniature examples were of symbolic, most probably of votive character (Hansen 1994, 204; Weihs 2004, 46; cf. Vachta 2008, 31; Novotná - Kvietok 2015, 222; Novotná - Furman 2018, 84-85, 89-90; Bř́za - Stuchlík 2019,83) or a form of a status symbol such as a sceptre (Teržan 1996, 246, sl. 1). As a sign/symbol, they undoubtedly had a leading role in the recognition of different cultural values of the Carpathian Basin, while their status outside of this milieu, for example in the hoards such as Peggau or the discussed hoard, needs additional efforts to be interpreted in context. In any case, these finds refute the hypotheses according to which they were interpreted as degenerate, dysfunctional or even scrap products inadequate for long-distance trade (Novotná - Furman 2018, 89, with earlier literature). The double pick from Moravička Sela remains, for now, the most southern find and could be understood as a specific subject of inter/transregional contacts and transmissions between individuals and societies (fig. 7).

An additional interpretative momentum was added by the physical characteristics of the double pick - it is an accurate, but miniature, reproduction/copy of the real pick. It is following all its formal characteristics, but the poorly manufacture could not be only the consequence of the small size (and difficult casting; cf. Novotná 1970b, 65). Several elements such as the irregular disc on the top and unremoved casting seams indicate that the artefact was produced with much less accuracy, attention and care for the details. It is formed as a symbolic artefact, but it was not produced as such. Further hypothesis, explaining the function of the miniature pick, could be suggested by the state of preservation of the sword. Nowadays, it is fragmented and bent, but it seems that these were consequences of two individual processes (fig. 3: 1). The sword was initially fragmented and the patina on the terminal part of the blade indicates that it was not only shortened but also re-sharpened - actually blunted. In a second act, the changed sword was violently destroyed - laterally stricken and bent. Reconstructing its biography we can conclude that 
the sword was initially produced as a formidable weapon and used as such, but at the same time as an instrument of public display of power, an insignia of the male social elite (Blečić Kavur - Kavur 2019). At the end of its life cycle, the sword was fragmented and blunted. It entered into its second cycle in which it retained the physical characteristics that could assure that it was still recognized as an emblem of the male social elite, but it was not an active weapon any more. At the end of the third cycle, it was violently destroyed, removed from public display, and positioned into an intentionally structured hoard. A question arising here is the role of the sword in its second life cycle - due to its shape it could not have been practically used as a sword. It remained just and recognizable symbol of the sword, a symbol of the social elite. Perhaps we are going too far but the blunt tip associates the modern observer with children's toys. Was the sword in the second cycle of its use transformed, through the different processes of knowledge, from an, with symbolism laden, weapon into an, with the same symbolism laden, toy? Yet, not a toy in a modern sense an element of mimicry, a carefully selected artefact used as an aid to learning the future symbolic use of the real artefact.

Were the miniature double pick and transformed sword artefacts used in the processes of ideological reproduction where junior members of the social elite were trained the proper use, manipulation and public display of (symbolic) artefacts? Was for them produced a specific material culture? Miniatures, produced with less care for this use only, displaying all the characteristics of the actual artefacts and transformed artefacts, real items made useless, but still preserving all the main formal characteristics necessary for their symbolic recognition (Blečić Kavur - Kavur 2019).

\section{The final act}

Since the hoard was most probably buried in a single event, we can interpret it as a permanently designated "act" of specific cultural gnosis following patterns from the tradition of a broader, but a contemporary, transcultural network of meanings. Thus, we can assume that the territory of Gorski Kotar and Kupa passage played an important role in the interaction of different cultural manifestations and social practices ranging from Pannonia to northern peak of the Adriatic (cf. Blečić Kavur 2014). The present hoard is special - it is chronologically determined and due to its content, it is stimulating different interpretations of its intentional composition. Not only since it is the first such find discovered on territory of the Gorski Kotar and Croatia, but and since the finds typologically and chronologically supplement the distribution of their types on a wider territory of the northern Adriatic and its direct hinterlands. Recognizing its importance and meaning, i.e. representation in a broader region, it enforces its connections with northern south-eastern Alpine region of Slovenia, e.g. Čremožiše, Črmošnjice, Gorenji Suhadol (Čerče - ك̌inkovec 1995; Križ - Stipančić 2007), eastern Karlovac region of Kupa (Perkić - Ložnjak Dizdar 2005, 42) and further along Sava Basin all the way to eastern Danube region in Serbia. Discoveries of two types of double picks in hoards of Jurka vas and Moravička Sela on one and from Serbian hoards Drenovac, Pećinci, Šimanovci and Šetonje on the other side of the southern Pannonian edge, do not only demonstrate long-distance contacts and trade (fig. 7). They are bearing witness to the integration of these territories into broader Pannonian-Carpathian cultural and ideological environment of the $13^{\text {th }}$ and $12^{\text {th }}$ century $\mathrm{BC}$. 
Most important, this integration is further confirmed by the presence of a miniature pick, an item that could demonstrate not only the local processes of social role learning and knowledge transfer, but most important the materialization of active Urnfield ideological system reproduction located on southern fringes of the Pannonian world. The hoard represents a set combined of local forms, which were emphatically upgraded, together with selectively appropriated forms and artefacts that signalled links not only to local but also to transcultural Carpathian social elites.

The study was made within the scope of the "Communities of the dead, societies of the living. Late Bronze Age of Eastern Slovenia” (J6-9363) project financed by the Slovenian Research Agency of the Republic of Slovenia.

We would like to thank to all that have helped in the study of the present hoard: Emil Crnković, Željko Bistrović, Ivo Mileusnić, Aca Đorđević, Jovan Mitrović, Aleksandar Jašarević and Milan Salaš.

\section{References}

Blečić Kavur, M. 2014: At the crossroads of worlds at the turn of the millennium: The Late Bronze Age in the Kvarner region. Katalozi i monografije 11. Zagreb: Arheološki muzej u Zagrebu.

Blečić Kavur, M. 2018: Kasnobrončanodobni dvokraki pijuci južnopanonskog prostora. In: L. Balj - D. Milanović eds., Naučni skup Srpskog arheološkog društva - Praistorijska sekcija, Novi Sad 14. decembra 2018, Novi Sad: Muzej Vojvodine, 17-18.

Blečić Kavur, M. - Jašarević, A. 2014: Kasnobrončanodobna ostava Majdan/Ridžali. Godišnjak Centra za balkanološka ispitivanja 43, 35-49.

Blečić Kavur, M. - Kavur, B. 2019: A small chieftain in a big wide world: on the reproduction of social roles in the Late Bronze Age... In: A. Tomaž ed., Material encounters; the miniature world of artefacts, Koper, $23^{\text {rd }}-24^{\text {th }}$ May 2019, Koper: Univerza na Primorskem, 8-9.

Bradley, R. 1998: The Passage of Arms: An archaeological analysis of prehistoric hoards and votive deposits. Oxford: Oxbow Books.

Bradley, R. 2013: Hoards and the deposition of metalwork. In: H. Fokkens - A. Harding eds., Handbook of the European Bronze Age, Oxford: Oxford University Press, 121-139.

Bř́za, S. - Stuchlík, S. 2019: Příspěvek k poznání dvojramenných mlatů na Moravě a v českém Slezsku. Pravěk NŘ 27, 75-64.

Brück, J. 2006: Fragmentation, personhood and the social construction of technology in Middle and Late Bronze Age Britain. Cambridge Archaeological Journal 16, 297-315.

Brück, J. 2016: Hoards, fragmentation and exchange in the European Bronze Age. In: S. Hansen et al. eds., Raum, Gabe und Erinnerung. Weihgaben und Heiligtümer in prähistorischen und antiken Gesellschaften, Berlin - Boston: De Gruyter, 75-92.

Церовић, М. 2005: Праисторијска остава из Дреновца. Museum: годишњак Народног музеја у Шапцу 6, $7-60$.

Chapman, J. 2000: Fragmentation in Archaeology: People, Places and Broken Objects in The Prehistory of South Eastern Europe. London: Routledge.

Čaplovič, P. 1957: Hromadný nález z Nižnej. Archeologické rozhledy 9, 775-777, 788.

Čerče, P. - Šinkovec, I. 1995: Catalogue of hoards of the Urnfield culture. In: B. Teržan ed., Hoards and Individual Metal Finds from the Eneolithic and Bronze Ages in Slovenia I. Katalogi in monografije 29, Ljubljana: Narodni muzej Slovenije, 129-232.

Dietrich, O. 2014: Learning from 'scrap' about Late Bronze Age hoarding practices. A biographical approach to individual acts of dedication in large metal hoards. European Journal of Archaeology 17, 468-486.

Dular, J. 1974: Bronasti jezičastoročajni meči iz Slovenije. In: M. Guštin ed., Varia Archaeologica I, Brežice, Posavski muzej Brežice, 11-29.

Furmánek, V. - Novotná, M. 2006: Die Sicheln in der Slowakei. Prähistorische Bronzefunde XVIII/6. Stuttgart: Franz Steiner Verlag. 
Hampel, J. 1886: A bronzkor emlékei Magyarhonban I. Budapest: Országos Régészeti és Embertani Társulat.

Hansen, S. 1994: Studien zu den Metalldeponierungen während der älteren Urnenfelderzeit zwischen Rhônetal und Karpatbecken. Universitätsforschungen zur prähistorischen Archäologie 21. Bonn: Verlag Dr. Rudolf Habelt $\mathrm{GmbH}$.

Hansen, S. 2005: Über bronzezeitliche Horte in Ungarn - Horte als soziale Praxis. In: B. Horejs et al. eds., Interpretationsraum Bronzezeit. Bernhard Hänsel von seinen Schülern gewidmet. Universitätsforschungen zur prähistorischen Archäologie 121, Bonn: Verlag Dr. Rudolf Habelt GmbH, 211-230.

Hansen, S. 2012: Bronzezeitliche Horte: Zeitliche und räumliche Rekontextualisierungen. In: S. Hansen et al. eds., Hort und Raum. Aktuelle Forschungen zu bronzezeitlichen Deponierungen in Mitteleuropa, Berlin - Boston: De Gruyter, 23-48.

Hansen, S. 2016: A short history of fragments in hoards of the Bronze Age. In: H. Baitinger ed., Materielle Kultur und Identität im Spannungsfeld zwischen Mediterraner Welt und Mitteleuropa, Römisch-Germanisches Zentralmuseum-Tagungen 27, Mainz: Verlag des Römisch-Germanischen Zentralmuseums, 185-208.

Harding, A. 1995: Die Schwerter im ehemaligen Jugoslawien. Prähistorische Bronzefunde IV, 14. Stuttgart: Franz Steiner Verlag.

Jacanović, D. - Radojčić, N. 2003: Praistorijska ostava metalnih predmeta iz sela Šetonje kod Petrovca na Mlavi. Viminacijum 13-14, 7-45.

Jovanović, D. B. 2010: Ostave Vršačkog gorja: Markovac - Grunjac. Vršac: Gradski muzej Vršac.

Kemenczei, T. 1988: Die Schwerter in Ungarn I (Griffplatten-, Griffangel- und Griffzungenschwerter). Prähistorische Bronzefunde IV, 6. Stuttgart: Franz Steiner Verlag.

Križ, B. - Stipančić, P. 2007: Gorjanci - Gorenji Suhadol. Varstvo spomenikov 43, 61-62.

Ložnjak Dizdar, D. 2011: Starija faza kulture polja sa žarama u sjevernoj Hrvatskoj - novi izazovi. In: M. Dizdar et al. eds., Starija faza kulture polja sa žarama u sjevernoj Hrvatskoj - novi izazovi, Osijek - Zagreb: Arheološki muzeji, 12-35.

Miroššayová, E. 1998/1999: Der Hortfund von Košické Olšany, Slowakei. Archäologie Österreichs - Sonderausgabe $9 / 10,122-129$.

Mozsolics, A. 2000: Bronzefunde aus Ungarn. Depotfundhorizonte Hajdúböszörmény, Románd und Bükkszentlászló. Prähistorische Archäologie in Südosteuropa 17. Kiel: Verlag Oetker Voges.

Müller-Karpe, H. 1959: Beiträge zur Chronologie der Urnenfelderzeit nördlich und südlich der Alpen. Römisch-Germanische Forschungen 22. Berlin: De Gruyter.

Nebelsick, L. 2000: Rent asunder: Ritual violence in Late Bronze Age hoards. In: C. F. E. Pare ed., Metals Make the World Go Round. The Supply and Circulation of Metals in Bronze Age Europe, Oxford: Oxbow, 160-175.

Novotná, M. 1970a: Die Bronzehortfunde in der Slowakei: Spätbronzezeit. Bratislava: Vydavatel'stvo SAV.

Novotná, M. 1970b: Die Äxte und Beile in der Slowakei. Prähistorische Bronzefunde IX, 3. München: C. H. Beck Verlag.

Novotná, M. 1980: Nezname bronzy zo Žitného ostrova. Archeologické rozhledy 32, 134-144.

Novotná, M. 1997: Bemerkungen zum Hortfund aus Vel'ký Blh. In: M. Lazić ed., Antidoron Dragoslavo Srejović completis LXV annis ab amicis collegis discipulis oblatum. Knjiga 17, Beograd: Univerzitet u Beogradu, Filozofski fakultet, 265-270.

Novotná, M. 2002: Ein Bronzesatz aus dem mittleren Waagtalgebiet in der Slowakei. Budapest régiségei XXXVI, 327-339.

Novotná, M. - Kvietok, M. 2015: Nové hromadné nálezy z doby bronzovej z Moštenice. Slovenská archeológia 63, 209-237.

Novotná, M. - Furman, M. 2018: Bronzový depot z Belej-Dulíc, okres Martin a dvojramenné čakany karpatskej proveniencie. Památky archeologické 109, 75-96.

Pare, C. F. E. 2013: Weighing, commodification and money. In: H. Fokkens - A. Harding eds., The Oxford Handbook of the European Bronze Age, Oxford: Oxford University Press, 508-527.

Patay, P. 1969: Der Bronzefund von Mezőkövesd. Acta Archaeologica Academiae Scientiarum Hungaricae 21, 167-216.

Pavlin, P. 1997: Bronastodobni jezičastoročajni srpi z Y-ornamentom. Arheološki vestnik 48, 27-40.

Pavlin, P. 2010: Bronastodobni jezičastoročajni srpi v jugovzhodni Evropi. Doctoral dissertation. University of Ljubljana.

Perkić, D. - Ložnjak Dizdar, D. 2005: The Siča/Lučica Late Bronze Age Hoard. Opvscvla Archaeologica 29, 41-119. 
Petrescu-Dâmbovița, M. 1978: Die Sicheln in Rumänien. Prähistorische Bronzefunde XVIII, 1. München: C. H. Beck Verlag.

Primas, M. 1986: Die Sicheln in Mitteleuropa I (Österreich, Schweiz, Süddeutschland). Prähistorische Bronzefunde XVIII, 2. München: C. H. Beck Verlag.

Radivojević, M. - Roberts, W. - Pernicka, E. - Stos-Gale, Z. - Martinón-Torres, M. - Rehren, T. - Bray, P. Brandherm, D. - Ling, J. - Mei, J. - Vandkilde, H. - Kristiansen, K. - Shennan, S. J. - Broodbank, C. 2018: The Provenance, Use, and Circulation of Metals in the European Bronze Age: The State of Debate. Journal of Archaeological Research 27, 131-185.

Rezi, B. 2011: Fragmentation in Late Bronze Age hoards from Transylvania. In: S. Berecki et al. eds., Bronze Age Rites and Ritual in the Carpathian Basin. Proceedings of the International Colloquium from Târgu Mureş 8-10 October 2010, Târgu Mureş: Mega, 303-334.

Salaš, M. 1997: Der urnenfelderzeitliche Hortfund von Polešovice. Brno: Moravské zemské muzeum.

Salaš, M. 2005: Bronzové depoty střední až pozdní doby bronzové na Moravě a ve Slezsku. Brno: Moravské zemské muzeum.

Salaš, M. 2018: Kovová depozita mladší doby bronzové z hradiska Réna u Ivančic. Brno: Moravské zemské muzeum.

Schauer, P. 1971: Die Schwerter in Süddeutschland, Österreich und der Schweiz I (Griffplatten-Griffangelund Griffzungenschwerter). Prähistorische Bronzefunde IV, 2. München: C. H. Beck Verlag.

Sommerfeld, C. 1994: Gerätegeld Sichel. Studien zur monetären Struktur bronzezeitlicher Horte im nördlichen Mitteleuropa. Vorgeschichtliche Forschungen 19. Berlin: De Gruyter.

Stuchlík, S. 1988: Bronzové sekeromlaty na Moravě. Památky archeologické 79, 269-328.

Šinkovec, I. 1995: Catalogue of individual metal finds from the Eneolithic and Bronze Ages. In: B. Teržan ed., Hoards and Individual Metal Finds from the Eneolithic and Bronze Ages in Slovenia I. Katalogi in monografije 29, Ljubljana: Narodni muzej Slovenije, 29-127.

Tarbay, G. 2014: Late Bronze Age depot from the foothills of the Pilis Mountains. Dissertationes Archaeologicae 3, 179-298.

Ţârlea, A. 2008: The concept of "selective deposition". Peuce VI, 63-132.

Teržan, B. 1996: Conclusion. In: B. Teržan ed., Hoards and Individual Metal Finds from the Eneolithic and Bronze Ages in Slovenia II. Katalogi in monografije 30, Ljubljana: Narodni muzej Slovenije, 243-258.

Turk, P. 1996: The Dating of Late Bronze Age Hoards. In: B. Teržan ed., Hoards and Individual Metal Finds from the Eneolithic and Bronze Ages in Slovenia II. Katalogi in monografije 30, Ljubljana: Narodni muzej Slovenije, 89-124.

Turk, P. 2012: Die Horte der Bronzezeit und ihre Fundplätze im „Kreuzungsbereich der Welten“. In: S. Hansen et al. eds., Hort und Raum. Aktuelle Forschungen zu bronzezeitlichen Deponierungen in Mitteleuropa, Berlin: De Gruyter, 211-226.

Vachta, T. 2008: Studien zu den bronzezeitlichen Hortfunden des oberen Theissgebietes. Universitätsforschungen zur prähistorischen Archäologie 159. Bonn: Verlag Dr. Rudolf Habelt GmbH.

Vasić, R. 1994: Die Sicheln im Zentralbalkan (Vojvodina, Serbien, Kosovo und Mazedonien). Prähistorische Bronzefunde XVIII, 5. Stuttgart: Franz Steiner Verlag.

Vinski-Gasparini, K. 1973: Kultura polja sa žarama u sjevernoj Hrvatskoj. Monografije 1. Zadar: Filozofski fakultet u Zadru.

Vinski-Gasparini, K. 1983: Kultura polja sa žarama sa svojim grupama. In: A. Benac - B. Čović eds., Praistorija jugoslavenskih zemalja IV - Brončano doba. Sarajevo: Centar za balkanološka ispitivanja Akademije nauka i umjetnosti Bosne i Hercegovine, 547-646.

Weihs, A. 2004: Der urnenfelderzeitliche Depotfund von Peggau (Steiermark). Universitätsforschungen zur prähistorischen Archäologie 114. Bonn: Verlag Dr. Rudolf Habelt GmbH.

MARTINA BLEČIĆ KAVUR, Univerza na Primorskem, Fakulteta za humanistične študije, Titov trg 5, SI-6000 Koper; martina.blecic.kavur@upr.si

BORIS KAVUR, Univerza na Primorskem, Fakulteta za humanistične študije, Titov trg 5, SI-6000 Koper

boris.kavur@upr.si

RANKO STARAC, Pomorski i povijesni muzej Hrvatskog primorja Rijeka, Muzejski trg 1, HR-51000 Rijeka

ranko.starac@ppmhp.hr 